\title{
"The regional allocation of labor resources in the context of economic restructuring and renewal: using a case from Russia"
}

\begin{tabular}{ll} 
& $\begin{array}{l}\text { Galina Khmeleva } \\
\text { Nicholay Tyukavkin } \\
\text { Olga Bulavko } \\
\text { Alina Prosvetova } \\
\text { Kristina Egorova }\end{array}$ \\
& $\begin{array}{l}\text { Galina Khmeleva, Nicholay Tyukavkin, Olga Bulavko, Alina Prosvetova and } \\
\text { Kristina Egorova (2017). The regional allocation of labor resources in the context } \\
\text { of economic restructuring and renewal: using a case from Russia. Problems and } \\
\text { Perspectives in Management, 15(3), 377-393. doi:10.21511/ppm.15(3-2).2017.07 }\end{array}$ \\
\hline ARTICLE INFO & http://dx.doi.org/10.21511/ppm.15(3-2).2017.07 \\
\hline DOI & Wednesday, 06 December 2017 \\
\hline RELEASED ON & Monday, 26 June 2017 \\
\hline RECEIVED ON & Wednesday, 06 September 2017 \\
\hline ACCEPTED ON & (cc) EY-No \\
\hline LICENSE & $\begin{array}{l}\text { This work is licensed under a Creative Commons Attribution-NonCommercial } 4.0 \\
\text { International License }\end{array}$ \\
\hline JOURNAL & "Problems and Perspectives in Management" \\
\hline ISSN PRINT & $1727-7051$ \\
\hline ISSN ONLINE & $1810-5467$ \\
\hline PUBLISHER & LLC “Consulting Publishing Company "Business Perspectives" \\
\hline FOUNDER & LLC “Consulting Publishing Company “Business Perspectives" \\
\hline
\end{tabular}

NUMBER OF REFERENCES

44
NUMBER OF FIGURES

0
NUMBER OF TABLES

9

(C) The author(s) 2023. This publication is an open access article. 


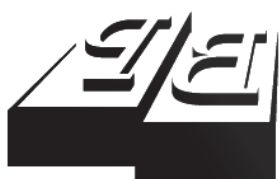

BUSINESS PERSPECTIVES

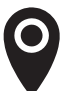

LLC "CPC "Business Perspectives" Hryhorii Skovoroda lane, 10, Sumy, 40022, Ukraine

www.businessperspectives.org

Received on: $26^{\text {th }}$ of June, 2017 Accepted on: $6^{\text {th }}$ of September, 2017

(C) Galina Khmeleva, Nicholay Tyukavkin, Olga Bulavko, Alina Prosvetova, Kristina Egorova, 2017

Galina Khmeleva, Doctor of Economics, Professor, Department of Regional Economics and Management, Samara State University of Economics, Russia, Samara University, Russia.

Nicholay Tyukavkin, Doctor of Economics, Professor, Department of Innovation Economics, Samara National Research University, Russia.

Olga Bulavko, Doctor of Economics, Professor, Department of Economics, Organization and Strategy of Enterprise Development, Samara State University of Economics, Russia.

Alina Prosvetova, Ph.D. (Economic Sciences), Department of Finance and Credit, Samara State University of Economics, Russia.

Kristina Egorova, Ph.D. Student, Samara State University of Economics, Russia.

\section{(ㄷ)(1) (8)}

This is an Open Access article, distributed under the terms of the Creative Commons Attribution-NonCommercial 4.0 International license, which permits re-use, distribution, and reproduction, provided the materials aren't used for commercial purposes and the original work is properly cited.
Galina Khmeleva (Russia), Nicholay Tyukavkin (Russia), Olga Bulavko (Russia), Alina Prosvetova (Russia), Kristina Egorova (Russia)

\section{THE REGIONAL ALLOCATION OF LABOR RESOURCES IN THE CONTEXT OF ECONOMIC RESTRUCTURING AND RENEWAL: USING A CASE FROM RUSSIA}

\begin{abstract}
The purpose of the article is to reveal the influence of the state policy of economic restructuring and renewal on the allocation of labor resources in regions and cities of the country. The state policy has an impact on the allocation of labor resources, but causes, at times, conflicting effects. This is especially true during the economic restructuring and renewal period. As a scientific and methodological basis, the analysis of the economic structure and the four-factor shift-share analysis, adapted by the authors in earlier works, were used. The use of statistical data of 98 cities in five federal districts of Russia in 2009-2015 allowed the authors to reveal the ambiguous influence of the state policy of economic restructuring and renewal on the allocation of labor resources by regions and cities of the country. It has been confirmed that the restructuring and renewal policy of the Russian economy, as well as in other countries, is accompanied by changes in the allocation of labor resources. As a positive effect, it can be noted that economic restructuring and renewal contribute to a balance in the spatial allocation of labor resources. As negative effects of economic restructuring and renewal, the authors of the article note the inertial nature of the economic structure (the extractive sector retains a leading position in terms of employment indicators) and a reduction in the labor potential of peripheral cities, which does not correspond to the stated goals of the economic restructuring and renewal policy. It is shown that the city authorities are able to exert a greater influence on changes in the economic structure than it is generally assumed. The authors believe that the states implementing the restructuring and renewal policy should take into account changes in the allocation of labor resources by regions and cities in order to observe the balance in regions' development and not to fall into a trap in which economic growth of regions attracting labor resources will be achieved at the expense of other regions.
\end{abstract}

Keywords

economic restructuring and renewal, allocation of labor resources, region, city, shift-share, administrative center, periphery, Russia

JEL Classification $\quad$ H790, L590, O018, R230, R580

\section{INTRODUCTION}

To ensure economic growth of the country, from time to time, there is a need to restructure and renew technological, economic and socio-political conditions for the sound functioning of society in order to make it more dynamic and increase economic competitiveness. Economic restructuring and renewal entail a number of consequences that can be avoided as a result of their timely identification and adoption of appropriate government measures.

Economic restructuring and renewal policy does not always achieve its goal, but it is always accompanied by changes in the allocation of labor resources, the consequences of which are of a long-term nature, can contribute to strengthening the uneven economic development of 
regions and cities. Overflows of labor resources lead to a reduction in the labor potential of previously successful regions and cities. The state that implements the economic restructuring and renewal policy risks falling into a trap in which economic growth is achieved at the expense of other regions. That is why it is important to identify manifestations in a timely manner that accompany economic restructuring and renewal in regions and cities.

In Russia, the need for the economic restructuring and renewal policy is relevant. This is due to a high dependence of the world market on the natural resources market, the import of technologies and hightech equipment. Real steps to implement the state economic restructuring and renewal policy were implemented in the late 2000s. The reactions to these processes are different: some are optimistic about the formation of a new economic structure, others believe that this will never happen. The Russian economy will continue to be dependent on natural resources. Gaddy and Ickes (2013) believe that, most likely, in the current conditions of Russia, the economic restructuring and renewal program will lead to negative results, because of the inefficient spatial allocation of physical and human capital.

\section{BRIEF LITERATURE REVIEW}

Economic restructuring and renewal as a scientific direction and mechanism of the state policy began to form in the post-war period, since there was the need for a rapid recovery of European economies. It is no accident that the ways for the rapid economic recovery of countries were based on the study material of Eastern and South-Eastern Europe (Rosenstein-Rodan, 1943; Staley, 1944).

Walt Whitman Rostow who singled out the stages of economic growth (traditional society, transition society the stage of "shift", the stage of "maturity", the era of "high mass consumption" (Rostow, 1952, 1960), the stage of searching for "quality of life" (Rostow, 1971) and justified that the transition to each subsequent stage should be consistent, made a significant contribution to the discussion on economic restructuring and renewal. You cannot skip to another stage without passing the previous one. But the next stage can be made on the basis of the state restructuring policy. There are two areas of research on the problem of economic restructuring and renewal. The first direction is connected with the search for imperatives of economic growth and economic development directions for the state policy. We can single out works, primarily representatives of developed countries of American and European economic schools (Solow, 1957; Lewis, 1959; Nurkse, 1955; Schumpeter, 1961; Bell, 1976; Perkins et al., 2001; Todaro \& Smith, 2009).
The second direction is related to the assessment of the consequences that took place in countries implementing economic restructuring and renewal with a view to moving to a new stage of economic growth by Rostow (for example, Tongxina, Yuejinb, \& Zhang Huan, 2011).

A special attention is paid to the works in which issues of economic restructuring and renewal in regions and cities are considered. Edgington (1989), examining the effects of economic restructuring and renewal using the example of the capital of Australia, Melbourne, noted the impact of the efficient operation of the capital economy on the overall functioning of the national economy, and also encouraged the government to pay more attention to the spatial aspects of industries' development, as this affects the economy of the country as a whole (Edgington, 1989).

Martynovich and Lundquist (2016), using the example of the study of the Swedish labor market, defined labor mobility as a mechanism for responding to economic shocks and found that key industries that stimulated technological changes were the main factors in attracting and retaining workers in regions.

In developing countries, researchers also carried out the study at the regional level. Fang, Wang Dewen, and Qu Yue (2009) drew attention to the fact that China's central and western provinces gained economic growth due to overflow effects and began to catch up with fast-growing regions. As a result, economic growth in these regions was more balanced (Fang et al., 2009). 
Tongxina, Fan Yuejinb and Zhang Huan (2011) note that thanks to the restructuring and renewal policy, China has turned from a backward agricultural country into the industrialized and information technology-based economy, and this process has been accompanied by profound structural changes.

In Russia, studies of interregional migration of labor resources at various stages of the country's economic development have been mainly conducted.

Such works include assessments of the consequences of interregional migration during the planned economy, the uniform distribution of the population in the country and the development of the eastern and northern regions (Hill \& Gaddy, 2003; Mikhailova, 2012a, 2012b), the assessments of the post-Soviet evolution of the urban system (Kolomak, 2017), the assessment of interregional mobility of the population (Guriev \& Andrienko, 2004).

The weakening attention on the part of the state towards the development of Siberia at the end of the $20^{\text {th }}$ and the beginning of the $21^{\text {st }}$ century was an incentive for weakening industry, for the outflow of Russians from this region in working age (Shabad, 1989; Nefedova, 2009; Gerasimenko, 2012) and for the inflow of foreign citizens from neighboring China.

The current stage of Russia's economic and foreign policy development is characterized by a turn to the East - the attention paid to the Asia-Pacific region is growing against the backdrop of worsening relations between Russia and the West (Graham, 2016). The question about the rate that this turn will take place and what forms it will acquire is the key one for the Russian state policy. It is especially relevant for the eastern territories of Russia, which face restructuring and renewal of the Russian economy, and they also face new challenges and new opportunities. Since population mobility has become one of the "development symbols and mottos of society" (Makhrova, Nefedova, \& Pallot, 2017), there is the further development trend of moving labor resources from the old industrial regions of Russia after new investment projects to the Far East and Siberia. The New Silk Road increases the interest to this topic. Russia, the largest country in the world, has more than 4 thousand $\mathrm{km}$. com- mon borders with China, is one of the main partners in the creation of the Chinese initiative - the New Silk Road. The movement to the North is the main direction of this initiative (Bennett, 2016). Although the China-Mongolia-Russia corridor is still in the planning stage, it is clear that the implementation of this project will require large-scale investments in key infrastructure facilities (roads, railways, ports, airports, telecommunications networks, pipelines, development of zones and cities) (Jin, 2015), which means that it will create new jobs.

\subsection{Establishing a research gap}

The literature review showed that foreign studies focus more on assessing the effectiveness of the economic restructuring and renewal policy, changing the economic structure, but not giving a comparative analysis of changes in employment both at the level of regions and at the level of individual cities in order to ensure regions' development. The research conducted in Russia concerned mainly interregional migration of labor resources and was carried out at the level of regions, but not cities. In conditions of a high proportion of the urban population, determining the importance of cities for the economies of countries, the study using the example of cities will help to deepen the understanding of the allocation of labor resources in the development of the economic restructuring and renewal policy.

\subsection{Aim of the study}

The purpose of the study is to determine the impact of the state economic restructuring and renewal policy on the allocation of labor resources by regions and cities of the country, and formulate the results of this influence.

The main questions of this study are whether the structural restructuring in cities began, what the differences between central and peripheral cities of regions in changing the economic structure are, what the impact of these changes on the uniformity of the allocation of labor resources across regions is?

To answer these questions, the authors used the analysis of indicators of the economic structure, the technique of the shift-share analysis, which 
introduced a local factor, that allowed closing the contour of factors for all four components: three levels of territorial division of the country and highlighting the impact of the industry conjuncture. The local factor allows studying the contribution of local economies and local authorities to the formation of the labor market structure.

Thus, the conclusions of this article are aimed at understanding ways to achieve uniformity in regions' development.

The main objects of the study were Russian cities, since the main labor potential of the country is concentrated in them. The share of the urban population in Russia is more than $70 \%$.

According to the goal, the results of the study consist of three parts. In the first part of the article, the authors will determine the general changes in the economic structure in all cities studied, as well as the differences in the concentration of labor potential in central and peripheral cities. In the second part of the article, the authors will show changes in the economic structure of cities and in the allocation of labor resources between regions. In the third part of the study, the authors will try to determine the role of city authorities in using competitive advantages of their territories in the context of economic restructuring and renewal.

This work is the continued cycle of studies of structural shifts in the economy in Russian cities (Khmeleva \& Bulavko, 2016; Khmeleva \& Egorova, 2016) and is conducted by scientists from several universities, as well as representatives of municipalities.

\section{MATERIALS AND METHODS}

First of all, it is necessary to determine the basic research concepts of the "region" and the "city". The concept and types of regions can be conceptualized in various ways depending on the research goal (for example, Gilbert, 1988). In modern science of regional management, the region is equally considered, like the city, as a rule, in a symbiosis of two positions: as a certain territory and as an economic system. In this context, the term "region" (city), is represented by the authors as a system of interrelated relations between authorities, enterprises and organizations of different types of activities, forms of activity and scales that carry out their activities in a certain territory. Primary linking of the region (city) to labor resources of organizations and sales markets allows providing sufficient justification for separation of territories on the basis of established functional links between workers, enterprises, organizations and markets for products and services (Dawkins, 2003). From the point of view of regional management, it is important to formalize administrative boundaries of regions and cities. Administrative territories are usually defined on a "top-down" basis in order to be responsible for exercising the powers of state and municipal government and ensuring lawfulness, while functional regions developed in interaction and integration, including within the traditional administrative borders (Zimmerbauer, 2013). Thus, territorial and functional approaches do not exclude, but complement each other.

In this article, the authors suggested holding to Dawkins' approach to the terms of the "region" and the "city", (Dawkins, 2003), but taking into account the state boundaries of city territories established by the state. Such an approach makes it possible to make appropriate calculations using official statistics.

Regarding the types of regions and cities, in order to solve research problems, it is possible to single out old industrial regions, which are usually referred to regions in which the territorial-production division of labor is characterized by the dominance of industrial branches with the predominance of obsolete technologies and means of production, low susceptibility to innovation (Coenen, Moodysson, \& Martin, 2015). The products of such industries often have a low level of science intensity, and sales markets are limited to the region or, at best, the country.

Regarding the methods for assessing the impact of economic restructuring and renewal on the allocation of labor resources by regions and cities, the authors took into account Edgington's findings (1989) who suggested that the main labor potential was in cities and was the basis for economic restructuring and renewing of the industrial type. 
Using the analysis of the employment dynamics by industry and type of activity in cities, it is possible to analyze the processes of economic restructuring and renewal. At the same time, it is necessary to take into account the high differentiation of regions in terms of population density. So, according to official data of Rosstat in 2015 in the North-West Federal District, the average population density was 8.5 people per sq. $\mathrm{km}$, in the Volga Federal District - 28.7 people per sq. km, in the Far Eastern Federal District - 1 person per sq. $\mathrm{km}$, in the Siberian Federal District - 3.8 people per sq. km, in the Ural Federal District -6.8 people per sq. $\mathrm{km}$. To ensure comparability of change indicators in the number of employees by federal districts, the calculation was carried out not in absolute terms, but in percentage terms.

To determine the factors influencing structural shifts in employment in regional studies, the Shiftshare analysis has shown a good performance.

In its traditional form, the three-factor shift-share analysis, proposed by Daniel Creamer (1940), was later formalized by Edgar S. Dunn (1960), and it continues to be widely used to identify the role of regional and national effects in shaping current economic trends (Artige \& Neuss, 2015).

The traditional three-factor shift-share analysis makes it possible to distinguish the influence of the national factor $\left(N S_{i}\right)$, the sectoral factor $\left(I M_{i}\right)$, the regional factor $\left(R S_{i}\right)$ as the cumulative change in the number of employed in organizations by type of activity (in the industry).

$$
\Delta l_{I}=l_{i, t}-l_{i, t-1}=N S_{i}+I M_{i}+R S_{i},
$$

where $\Delta l_{I}$ - the absolute change of the indicator at the local level; $l_{i, t}$ - the value of the indicator at the level of the local area (for example, a city, a village) in a particular industry in the last year under study; $l_{i, t-1}$ - the value of the indicator at the level of the local area in a particular industry in the first year under study; $N S_{i}$ - the national factor (at the country level); $I M_{i}$ - the sectoral factor; $R S_{i}$ - the regional factor (region).

This analysis is applicable to research on the allocation of labor resources, employment issues in industries at the regional level, since it allows as- sessing the impact of the national policy $\left(N S_{i}\right)$, changes in the industry situation $\left(I M_{i}\right)$, and the influence of regional proportions which are under the influence of the policy of regional authorities $\left(R S_{i}\right)$.

In the work of Khmeleva and Egorova (2016), the traditional three-factor analysis was adapted to meet the challenges of analyzing the structural shifts in the urban employment. For this, the local factor $L S_{i}$ was introduced into the traditional three-factor analysis.

Then the generalized four-factor shift-share analysis will take the following form:

$$
\Delta l_{I}=l_{i, t}-l_{i, t-1}=N S_{i}+I M_{i}+R S_{i}+L S_{i},
$$

where $L S_{i}$ - the local factor (the local area).

The national factor (at the country level):

$$
N S_{i}=l_{i, t-1} \cdot \frac{E_{t}-E_{t-1}}{E_{t-1}},
$$

where $l_{i, t-1}$ - the value of the indicator at the level of the municipal entity in a particular industry in the first year under study; $E_{t}-$ the value of the indicator as a whole for the country in the last year under study; $E_{t-1}$ - the value of the indicator as a whole for the country in the first year under study.

The sectoral factor:

$I M_{i}=l_{i, t-1} \cdot\left(\frac{E_{i, t}-E_{i, t-1}}{E_{i, t-1}}-\frac{E_{t}-E_{t-1}}{E_{t-1}}\right)$,

where $E_{i, t}$ - the value of the indicator at the country level in a particular industry in the last year under study; $E_{i, t-1}$ - the value of the indicator at the country level in a particular industry in the first year under study.

The regional factor:

$R S_{i}=l_{i, t-1} \cdot\left(\frac{e_{i, t}-e_{i, t-1}}{e_{i, t-1}}-\frac{E_{i, t}-E_{i, t-1}}{E_{i, t-1}}\right)$,

where $e_{i, t}$ - the value of the indicator at the regional level in a particular industry in the last year under study; $e_{i, t-1}$ - the value of the indicator at the regional level in a particular industry in the first year under study. 
The local factor:

$$
L S_{i}=l_{i, t-1} \cdot\left(\frac{l_{i, t}-l_{i, t-1}}{l_{i, t-1}}-\frac{e_{i, t}-e_{i, t-1}}{e_{i, t-1}}\right),
$$

where $l_{i, t}, l_{i, t-1}$ - the number of people employed on the local area in a particular industry in the current and base periods, respectively.

Then the total change in the number of employed in the city can be explained by the influence of four effects:

$$
\sum \Delta l=\sum N S+\sum I M+\sum R S+\sum L S
$$

The national effect $\left(\sum N S\right)$ is formed under the influence of the total employment dynamics in the country during the period under study.

The effect of the national industry conjuncture $\left(\sum I M\right)$ is the result of changes in the demand for labor by certain activities at the country level. The positive effect of the sectoral conjuncture $\left(\sum I M>0\right)$ is observed if the economic structure of the city corresponds to national trends. Conversely, a negative effect $\left(\sum I M<0\right)$ is observed if the economic structure of the city contradicts national trends. The greater the discrepancy between local and national employment structures, the greater the impact of this factor.

The effect of regional proportions $\left(\sum R S\right)$ is formed under the influence of the national and regional economic structure, and it shows how the economic structure of the city meets national and regional proportions. The effect of territorial competitiveness $\left(\sum L S\right)$ shows how competitive advantages are used in the city. When $\left(\sum L S>0\right)$, then this indicates that the economic structure of the city corresponds to regional proportions, favorable conditions for the population are created in the city, the labor potential is increasing. The negative effect of territorial competitiveness $\left(\sum L S<0\right)$ indicates that there is the unfavorable economic structure for the city's development. Proceeding from the assumption that the formation of the economic structure of the city is not a chaotic but purposeful management process, the leading role in which is assigned to city authorities, the article assesses the influence of city authorities on the restructuring of the urban economy on the basis of the magnitude and orientation analysis of the local factor.
The proposed model supplements the already existing variations of the shift-share analysis: the four-factor model of Esteban-Marquillas (1972), the extended model (Arcelus, 1988), the dynamic model (Wilson et al., 2005).

\section{EXPERIMENTAL RESEARCH BASE}

In this study, the analysis of the economic structure is conducted across 98 Russian cities of the North-Western Federal District, the Volga Federal District, the Urals Federal District, the Siberian Federal District and the Far Eastern Federal District for the entire period 2009-2015. The sources of information were the official data of the Federal State Statistics Service of the Russian Federation on the average annual number of employees in organizations by type of activity (excluding small businesses) according to the All-Russian Classification of Economic Activities (OKVED 2) OK 029-2014.

In addition to the analysis of the structure by type of activity, the cities are divided into two types:

"capital" - the administrative center of the region;

- "peripheral" - all other cities in the region.

It is generally accepted that the most active and professional part of the region's population lives in "capitals" (administrative centers of the region). Residents of administrative centers are more flexible in making decisions about moving because they need to find a job, because they have an opportunity to get high-quality education and receive a higher income from their professional activities than residents of peripheral cities. In large Russian administrative centers, there are research centers, the vast majority of innovation infrastructure, enterprises in various fields of activity.

\subsection{Stages of research}

The identification of the impact of economic restructuring and renewal on the allocation of labor resources by regions and cities was carried out in two stages. 
Table 1. Changes in the number of employees in organizations in $2009-2015, \%$

Source: calculated by the authors according to Rosstat.

\begin{tabular}{l|c|c|c|c|c|c|c}
\hline $\begin{array}{c}\text { Federal } \\
\text { districts }\end{array}$ & $\begin{array}{c}\text { The } \\
\text { Volga } \\
\text { FD }\end{array}$ & $\begin{array}{c}\text { The North-Western } \\
\text { FD (excluding Saint } \\
\text { of cities }\end{array}$ & $\begin{array}{c}\text { The North-Western } \\
\text { FD (including Saint } \\
\text { Petersburg) }\end{array}$ & $\begin{array}{c}\text { The } \\
\text { Urals } \\
\text { FD }\end{array}$ & $\begin{array}{c}\text { The Far } \\
\text { Eastern } \\
\text { FD }\end{array}$ & $\begin{array}{c}\text { The } \\
\text { Siberian } \\
\text { FD }\end{array}$ \\
\hline Total & -9.01 & -10.93 & -4.09 & -5.38 & -1.89 \\
Capitals of regions & -7.56 & -11.87 & -1.67 & -2.81 \\
\hline Periphery cities & -13.89 & -8.48 & -8.48 & -11.41 & -9.33 \\
\hline
\end{tabular}

At the first stage, the authors used the indicator of the number of employees in organizations by type of activity, which allowed assessing changes in the economic structure of regions and cities during the period under study.

At the second stage, to assess how cities are using their competitive advantages in the conditions of economic restructuring and renewal, the authors used the shift-share analysis, which was tested in previous studies by the authors when solving the problem of analyzing structural shifts in urban employment (Khmeleva \& Egorova, 2016).

\subsection{Results}

General changes in the economic structure of all cities are studied. The labor potential of cities is reduced and concentrated in "capitals" of regions.

Reduction in the number of employees in organizations is observed in all analyzed federal districts, and in peripheral cities, it is 3.5 times higher than in capitals (Table 1).

In the context of federal districts, things are worse in the Volga Federal District. In the North-Western Federal District, the large city region of St. Petersburg - an economic, business and cultural center that allocates labor resources, not only for the North-Western part of the country, but also for other regions of the country, substantially alleviates the situation. The St. Petersburg agglomeration is the second most important in the country after the Moscow capital region (Kolomak, 2017).

Thus, without taking into account the data of St. Petersburg, the decrease in the number of employees in organizations in the North-Western
Federal District amounted to $11.87 \%$, which is significantly higher than other federal districts under study. The number of employees in organizations in cities of the Far Eastern and Siberian Federal Districts has decreased to a lesser extent.

\subsubsection{The Expansion of the Service Industry Continues in Cities}

The data show that the fundamental trend of 2009, which determined the profile of the urban economy, both large and small, was the expansion of the service sector (Table 2). The share of employed in the service sector in 2015 came close to $70 \%$, while in 2009 , it was $66.6 \%$. At the same time, the only sector with the positive growth dynamics of employees, more than a third, was trade, auto repair and household services, which is explained by the expansion of coverage areas of large retailers in regions, as well as the development of personal services in connection with the continuously increasing requirements for living standards.

Table 2 shows the structure of employed in enterprises and organizations of cities, according to which the study was conducted.

The data in Table 2 show that, as it was in previous years, the real sector in the urban economy is reducing. And although a significant share is occupied by those employed in the manufacturing sector, this share decreased by $1.82 \%$, giving way to the service economic sectors: trade and services to the population. Because of the specific nature of urban work, the number of employees in organizations by "agriculture" activity is the lowest, which underlines the low importance of this sector for the development of the urban economy. 
Table 2. Dynamics of the number of employees in organizations in all cities studied in 2009-2015

Source: calculated by the authors according to Rosstat.

\begin{tabular}{|c|c|c|c|c|}
\hline \multirow[t]{2}{*}{ Table line names } & \multicolumn{2}{|c|}{$\begin{array}{l}\text { The number of } \\
\text { employees in } \\
\text { organizations, } \\
\text { thousand people }\end{array}$} & \multicolumn{2}{|c|}{ The share, $\%$} \\
\hline & 2009 & 2015 & 2009 & 2015 \\
\hline Education & 1317,06 & 1188,93 & 13.23 & 12.85 \\
\hline Hotels and restaurants & 113,76 & 93,59 & 1.14 & 1.01 \\
\hline Mining & 162,02 & 142,97 & 1.63 & 1.55 \\
\hline Other activities & 1354,48 & 1336,19 & 13.61 & 14.44 \\
\hline Health and social services & 1105,50 & 1058,26 & 11.11 & 11.44 \\
\hline Manufacturing & 2209,63 & 1885,68 & 22.20 & 20.38 \\
\hline Real estate operations, renting services & 751,40 & 739,06 & 7.55 & 7.99 \\
\hline $\begin{array}{l}\text { Wholesale and retail trade; repair of motor vehicles, motorcycles, } \\
\text { household products and personal items }\end{array}$ & 551,39 & 732,94 & 5.54 & 7.92 \\
\hline Other communal, social and personal services & 335,03 & 313,80 & 3.37 & 3.39 \\
\hline Production and distribution of electricity, gas and water & 464,46 & 437,83 & 4.67 & 4.73 \\
\hline Agriculture, hunting and forestry & 54,60 & 45,41 & 0.55 & 0.49 \\
\hline Construction & 445,41 & 345,04 & 4.48 & 3.73 \\
\hline Transport and communication & 1087,10 & 932,52 & 10.92 & 10.08 \\
\hline Total & 9951,84 & 9252,22 & 100.00 & 100.00 \\
\hline
\end{tabular}

Below the authors consider changes in the number of employees in organizations in 2009-2015 by type of activity (Table 3).

The manufacturing sector in "peripheral" cities is reduced 2 times higher than in regional "capitals", which is a consequence of the long-term continu- ing destruction of the industrial potential of the urban economy in the Russian province. As a result, in "peripheral" cities the demand for workers in production and distribution of electricity, gas and water sector is reduced by $13.84 \%$, the negative dynamics is observed in construction - more than $27 \%$ in comparison with the level of 2009.

Table 3. Changes in the number of employees in organizations in capital and peripheral cities, 2009-2015, \%

Source: calculated by the authors according to Rosstat.

\begin{tabular}{|c|c|c|c|}
\hline \multirow{2}{*}{ Type of activity } & \multirow{2}{*}{ Changes for the period in total } & \multicolumn{2}{|c|}{ Including } \\
\hline & & Capital cities & Peripheral cities \\
\hline Education & -9.58 & -9.65 & -9.36 \\
\hline Hotels and restaurants & -17.86 & -12.56 & -29.15 \\
\hline Mining & -11.76 & 28.33 & -21.14 \\
\hline Other activities & -1.20 & -0.50 & -4.68 \\
\hline Health and social services & -4.12 & -5.07 & -0.83 \\
\hline Manufacturing & -12.74 & -10.67 & -16.40 \\
\hline Real estate operations, renting services & -1.52 & -0.73 & -4.66 \\
\hline $\begin{array}{l}\text { Wholesale and retail trade; repair of motor } \\
\text { vehicles, motorcycles, household products } \\
\text { and personal items }\end{array}$ & 33.02 & 33.45 & 30.63 \\
\hline $\begin{array}{l}\text { Other communal, social and personal } \\
\text { services }\end{array}$ & -6.21 & -5.66 & -7.92 \\
\hline $\begin{array}{l}\text { Production and distribution of electricity, gas } \\
\text { and water }\end{array}$ & -5.64 & -2.42 & -13.84 \\
\hline Agriculture, hunting and forestry & -21.81 & -16.20 & -40.44 \\
\hline Construction & -22.42 & -19.94 & -27.74 \\
\hline Transport and communication & -14.15 & -14.91 & -11.55 \\
\hline Total & -6.65 & -4.91 & -11.57 \\
\hline
\end{tabular}




\subsubsection{Changes in the economic structure of cities and in the allocation of labor resources between regions. Cities of the North- Western Federal District}

In cities of the North-Western Federal District (excluding St. Petersburg), the outflow of personnel is observed; the trade and services sector is expanding more actively than in other regions due to reduction in the number of employees in organizations in industry.

The North-Western Federal District includes 10 regions (the Republic of Karelia, the Komi Republic, the Arkhangelsk Region, the Nenets Autonomous District, the Arkhangelsk Region, the Vologda Region, the Kaliningrad Region, the Leningrad Region, the Murmansk Region, the Novgorod Region, the Pskov Region) and one city region St. Petersburg. The subjects of the Russian Federation of the North-Western Federal District account for $10 \%$ of the total number of employed in Russia. Calculations in the article were conducted for 15 administrative centers and peripheral cities, which is $37.5 \%$ of the total number of cities in this federal district. The main strategic function of the NorthWestern Federal District of the region in the field of economy is to maintain foreign economic rela- tions with the European Union and a number of other countries of the world. This led to the rapid development of transport infrastructure, as well as the orientation of a significant part of the business on servicing foreign economic relations.

In cities of the North-Western Federal District, the economic structure as a whole is in line with general trends. It is worth noting that the manufacturing sector has the most negative dynamics. At the same time, in "peripheral" cities the decrease in the number of employees in organizations as a whole is $67.95 \%$, in "capital" cities - 19.31\% (Table 4).

As a result, the share of the manufacturing sector for the period from 2009 decreased by $5 \%$ and amounted to $12.17 \%$ in 2015 , which looks critical for the further development of the industrial potential of cities in the North-Western Federal District.

The number of employees in organizations of the mining sector decreased by $53.46 \%$ in "peripheral" cities. A small growth of $2.05 \%$ in the number of employees in organizations of the mining sector of capital cities compensated for such a significant decline, which generally did not affect the overall employment situation in the industry.

Table 4. Changes in the number of employees in organizations in cities of the North-Western Federal District, 2009-2015*, \%

Source: calculated by the authors according to Rosstat.

\begin{tabular}{|c|c|c|c|c|}
\hline \multirow{3}{*}{ Type of activity } & \multirow{3}{*}{$\begin{array}{l}\text { The share } \\
\text { of total } \\
\text { employment } \\
\text { in } 2015\end{array}$} & \multicolumn{3}{|c|}{ Changes in the number of employees in organizations } \\
\hline & & \multirow{2}{*}{ Total } & \multicolumn{2}{|c|}{ Including } \\
\hline & & & Capital cities & Peripheral cities \\
\hline Education & 14.50 & -11.05 & -10.47 & -12.63 \\
\hline Hotels and restaurants & 1.03 & -16.22 & -12.63 & -24.97 \\
\hline Mining & 1.09 & -46.69 & 2.05 & -53.46 \\
\hline Other activities & 18.26 & -11.95 & -13.14 & -5.27 \\
\hline Health and social services & 12.89 & -1.88 & -1.34 & -3.40 \\
\hline Manufacturing & 12.17 & -40.05 & -19.31 & -67.95 \\
\hline Real estate operations, renting services & 6.46 & -9.97 & -7.31 & -16.24 \\
\hline $\begin{array}{l}\text { Wholesale and retail trade; repair of } \\
\text { motor vehicles, motorcycles, household } \\
\text { products and personal items }\end{array}$ & 7.25 & 12.15 & 8.80 & 37.74 \\
\hline $\begin{array}{l}\text { Other communal, social and personal } \\
\text { services }\end{array}$ & 4.27 & -12.21 & -12.72 & -10.47 \\
\hline $\begin{array}{l}\text { Production and distribution of electricity, } \\
\text { gas and water }\end{array}$ & 5.63 & -8.62 & -10.76 & -2.35 \\
\hline Agriculture, hunting and forestry & 0.67 & -26.48 & -9.21 & -61.36 \\
\hline Construction & 3.31 & -15.42 & -23.61 & 6.93 \\
\hline Transport and communication & 12.46 & -18.30 & -23.07 & -5.77 \\
\hline Total & 100.00 & -10.93 & -11.87 & -8.48 \\
\hline
\end{tabular}

Note: ${ }^{\star}$ excluding the data for St. Petersburg. 


\subsubsection{Cities of the Volga Federal District}

In the Volga Federal District, there is the largest decrease in the number of employees in organizations in "peripheral" cities than in other regions; the mining sector is expanding, the manufacturing and construction sectors are significantly reduced.

The Volga Federal District includes regions-subjects of the Russian Federation (the Republic of Bashkortostan, the Republic of Mari El, the Republic of Mordovia, the Republic of Tatarstan, the Udmurt Republic, the Chuvash Republic, Perm Krai, the Kirov Region, the Nizhny Novgorod Region, the Orenburg Region, the Penza Region, the Samara Region, the Saratov Region, the Ulyanovsk Region). This is one of the most densely populated regions, in which more than $20 \%$ of the total working population of the country lives. The main profile of the modern economic structure of the Volga Federal District was formed during the period of the planned economy and did not undergo significant changes during the period of market reforms. Favorable for living and doing business, natural and climatic conditions, availability of natural and manpower resources determined such types of specialization as extractive industry, machine building and petrochemical industry. The construction and building materials industry, transport and energy were also developed here.

In cities of the Volga Federal District, the outflow of personnel from enterprises and organizations of peripheral cities is high compared to other regions (Table 5).

It should be noted that cities of the Volga Federal District are characterized by a high proportion of the number of employees in organizations by types of industrial activity (manufacturing, mining) in the economic structure. However, this share decreased by $1.72 \%$ (173 thousand people) from 2009 to 2015 . The main contribution to this reduction is made by peripheral cities $(-21.41 \%$, or 90 thousand people).

Cities of the Volga Federal District are distinguished by a high growth in the number of employed in organizations of the mining sector - by $33.51 \%$ (11.5 thousand people), but overall the importance of this sector in the economic structure remains low, at $1.14 \%$. A significant increase in the number of employees is observed in trade and service organizations (70.5 thousand people).

Table 5. Changes in the number of employees in organizations in cities of the Volga Federal District, 2009-2015, \%

Source: calculated by the authors according to Rosstat.

\begin{tabular}{|c|c|c|c|c|}
\hline \multirow{3}{*}{ Type of activity } & \multirow{3}{*}{$\begin{array}{l}\text { The share } \\
\text { of total } \\
\text { employment in } \\
2015\end{array}$} & \multicolumn{3}{|c|}{$\begin{array}{c}\text { Changes in the number of employees in } \\
\text { organizations }\end{array}$} \\
\hline & & \multirow{2}{*}{ Total } & \multicolumn{2}{|c|}{ Including } \\
\hline & & & Capital cities & Peripheral cities \\
\hline Education & 12.65 & -10.98 & -10.78 & -11.69 \\
\hline Hotels and restaurants & 0.96 & -24.23 & -17.86 & -40.73 \\
\hline Mining & 1.14 & 33.51 & 18.04 & 59.09 \\
\hline Other activities & 12.70 & -3.56 & -3.52 & -3.82 \\
\hline Health and social services & 10.97 & -9.93 & -12.75 & 2.97 \\
\hline Manufacturing & 25.60 & -14.35 & -10.31 & -21.41 \\
\hline Real estate operations, renting services & 8.01 & -2.50 & -2.86 & -0.35 \\
\hline $\begin{array}{l}\text { Wholesale and retail trade; repair of motor } \\
\text { vehicles, motorcycles, household products and } \\
\text { personal items }\end{array}$ & 8.04 & 27.82 & 28.30 & 25.32 \\
\hline Other communal, social and personal services & 3.16 & -7.24 & -6.55 & -10.14 \\
\hline $\begin{array}{l}\text { Production and distribution of electricity, gas and } \\
\text { water }\end{array}$ & 4.44 & -8.55 & -5.12 & -20.39 \\
\hline Agriculture, hunting and forestry & 0.49 & -25.19 & -20.07 & -45.86 \\
\hline Construction & 3.08 & -22.87 & -20.55 & -30.47 \\
\hline Transport and communication & 8.76 & -17.44 & -18.26 & -12.27 \\
\hline Total & 100.00 & -9.01 & -7.56 & -13.89 \\
\hline
\end{tabular}




\subsubsection{Cities of the Ural Federal District}

In cities of the traditionally industrial Urals Federal District, the number of employees is decreasing, but insignificantly; the trade and household services sector is actively expanding.

The Urals Federal District unites 6 regions of the RussianFederation: the Yamal-Nenets Autonomous District, the Khanty-Mansi Autonomous DiatrictYugra, the Tyumen, Sverdlovsk, Chelyabinsk and Kurgan Regions.

The Urals Federal District has a unique natural resource potential, developed industrial complex, powerful, though unevenly developed, transport and energy infrastructure, a high share of export products, skilled labor resources, an extensive network of educational and research centers. The number of employees in organizations in cities of the Urals Federal District decreased, but at a slower rate than in the North-Western and Volga Federal Districts (Table 6).

It is worth paying attention to the fact that in the region with traditionally industrial specifics, the trade and services sector is significantly expanding, which is consistent with the worldwide trend.
The share of the number of employees in organizations in the mining sector of the Urals Federal District is more than 2 times higher than the average for the regions under study, but it significantly reduced from $4.62 \%$ in 2009 to $3.42 \%$ in 2015 . At the same time, the number of people employed in the mining sector significantly increased in Nefteyugansk, Surgut, Tyumen. The negative dynamics are typical for traditionally oil and gas producing cities: Nizhnevartovsk, Nyagan, Kogalym, Novy Urengoy. In Tyumen, the increase in the number of workers in the mining sector amounted to 5.4 times, which ultimately affected the growth of the indicator as a whole for the federal district.

In the economic structure of cities of the Ural Federal District, the main share is also occupied by the manufacturing sector, the decline is lower than the national average, and it is relatively evenly distributed between capital cities and peripheral cities.

\subsubsection{Cities of the Far Eastern Federal District}

Cities of the Far Eastern Federal District are the most stable in terms of the number of employees in organizations. The border cities Khabarovsk, Vladivostok and Blagoveshchensk are becoming centers of international trade.

Table 6. Changes in the number of employees in organizations in cities of the Ural Federal District, 2009-2015, \%

Source: calculated by the authors according to Rosstat.

\begin{tabular}{|c|c|c|c|c|}
\hline \multirow{3}{*}{ Type of activity } & \multirow{3}{*}{$\begin{array}{l}\text { The share } \\
\text { of total } \\
\text { employment in } \\
2015\end{array}$} & \multicolumn{3}{|c|}{$\begin{array}{c}\text { Changes in the number of employees in } \\
\text { organizations }\end{array}$} \\
\hline & & \multirow{2}{*}{ Total } & \multicolumn{2}{|c|}{ Including } \\
\hline & & & Capital cities & Peripheral cities \\
\hline Education & 11.75 & -7.42 & -8.50 & -5.80 \\
\hline Hotels and restaurants & 1.13 & -23.05 & -24.75 & -21.41 \\
\hline Mining & 3.42 & -29.96 & 39.13 & -31.57 \\
\hline Other activities & 13.12 & 1.34 & 5.12 & -6.29 \\
\hline Health and social services & 10.50 & 3.12 & 6.75 & -2.12 \\
\hline Manufacturing & 20.25 & -8.63 & -7.86 & -9.64 \\
\hline Real estate operations, renting services & 7.90 & 0.07 & 5.35 & -6.29 \\
\hline $\begin{array}{l}\text { Wholesale and retail trade; repair of motor } \\
\text { vehicles, motorcycles, household products and } \\
\text { personal items }\end{array}$ & 8.04 & 44.75 & 47.18 & 36.26 \\
\hline Other communal, social and personal services & 3.28 & 0.17 & 1.17 & -0.89 \\
\hline $\begin{array}{l}\text { Production and distribution of electricity, gas and } \\
\text { water }\end{array}$ & 4.53 & -9.01 & -5.32 & -12.55 \\
\hline Agriculture, hunting and forestry & 0.34 & -29.82 & -21.24 & -52.53 \\
\hline Construction & 4.84 & -26.71 & -20.95 & -30.72 \\
\hline Transport and communication & 10.91 & -13.21 & -12.77 & -13.81 \\
\hline Total & 100.00 & -5.38 & -0.58 & -11.41 \\
\hline
\end{tabular}


The Far Eastern Federal District includes 9 subjects of the Russian Federation (the Republic of Sakha (Yakutia), the Kamchatka Territory, the Primorsky Territory, the Khabarovsk Territory, the Amur Region, the Magadan Region, the Sakhalin Region, the Jewish Autonomous Region, the Chukotka Autonomous District). The Far Eastern District is characterized by the lowest density of population in Russia and extremely low level of infrastructural security, including transport infrastructure. Table 7 presents data on cities of the Far Eastern Federal District.

Despite the fact that the share of the manufacturing sectoris lower than the Russian average, unlike in other regions, there is an insignificant increase in the number of employees $-2.05 \%$ in cities - administrative centers of the federal district. Only in Petropavlovsk-Kamchatsky, the growth of workers in manufacturing amounted to more than 5 thousand people, and more than a thousand people in Vladivostok.

In the district, the share of wholesale and retail trade, repair of motor vehicles, motorcycles, household goods and personal items is growing rapidly, making $6.22 \%$ in 2015 (in $2009-4.16 \%$ ). The border position of Khabarovsk with China, Vladivostok with Japan, Blagoveshchensk with
China determined the influx of workers into this sector: +5.7 thousand people, +4.3 thousand people, +2.1 thousand people, respectively.

\subsubsection{Cities of the Siberian Federal District}

In cities of the Siberian Federal District, there are higher growth rates in the number of workers in organizations engaged in the mining sector, as well as in the trade and consumer services sector than in other regions.

The Siberian Federal District includes 12 regions subjects of the Russian Federation (the Republic of Altai, the Republic of Buryatia, the Republic of Tyva, the Republic of Khakassia, the Altai Territory, the Transbaikal Territory, the Krasnoyarsk Territory, the Irkutsk Region, the Kemerovo Region, the Novosibirsk Region, the Omsk Region, the Tomsk Region). The main reserves of natural resources are concentrated (for example, $80 \%$ of coal, $70 \%$ of copper, $68 \%$ of nickel) in this federal district. Thanks to the developed railway infrastructure, the Siberian Federal District is a natural transport bridge between the countries of Western Europe, North America and East Asia.

Table 8 presents data on cities of the Siberian Federal District. Leaders were Krasnoyarsk (+6

Table 7. Changes in the number of employees in organizations in cities of the Far Eastern Federal District, 2009-2015, \%

Source: calculated by the authors according to Rosstat.

\begin{tabular}{|c|c|c|c|c|}
\hline \multirow{3}{*}{ Type of activity } & \multirow{3}{*}{$\begin{array}{c}\text { The share } \\
\text { of total } \\
\text { employment } \\
\text { in } 2015\end{array}$} & \multicolumn{3}{|c|}{$\begin{array}{c}\text { Changes in the number of employees in } \\
\text { organizations }\end{array}$} \\
\hline & & \multirow{2}{*}{ Total } & \multicolumn{2}{|c|}{ Including } \\
\hline & & & Capital cities & Peripheral cities \\
\hline Education & 11.34 & -12.85 & -13.54 & -10.15 \\
\hline Hotels and restaurants & 1.36 & 13.24 & 26.14 & -34.31 \\
\hline Mining & 0.48 & 30.63 & 49.84 & - \\
\hline Other activities & 22.14 & 15.56 & 14.93 & 22.07 \\
\hline Health and social services & 11.46 & 0.72 & 0.59 & 1.25 \\
\hline Manufacturing & 9.38 & -7.99 & 2.05 & -18.46 \\
\hline Real estate operations, renting services & 8.12 & -2.14 & -2.19 & -1.70 \\
\hline $\begin{array}{l}\text { Wholesale and retail trade; repair of motor vehicles, } \\
\text { motorcycles, household products and personal items }\end{array}$ & 6.22 & 46.65 & 48.57 & 34.99 \\
\hline Other communal, social and personal services & 3.44 & 0.09 & 1.22 & -4.12 \\
\hline $\begin{array}{l}\text { Production and distribution of electricity, gas and } \\
\text { water }\end{array}$ & 6.34 & 3.38 & 8.05 & -23.12 \\
\hline Agriculture, hunting and forestry & 0.78 & -10.84 & -10.58 & -11.40 \\
\hline Construction & 5.15 & -27.55 & -22.96 & -43.43 \\
\hline Transport and communication & 13.79 & -16.54 & -19.67 & -6.11 \\
\hline Total & 100.00 & -1.89 & 0.00 & -9.33 \\
\hline
\end{tabular}


thousand people), Norilsk (+3.8 thousand people) and Irkutsk (0.663 thousand people), outsiders Omsk ( -15.5 thousand people) Bratsk ( -7.6 thousand people) and Usolye-Siberian (-6.2 thousand people).

The Siberian Federal District is characterized by high rates of expansion of the mining sector in capital cities of the region, the increase in the number of employees in which amounted to $91.52 \%$ over the last 6 years. The number of workers in the manufacturing sector is declining, although at a lower rate than the national average. As a result, the share of workers in the manufacturing sector fell by $2 \%$, partly offset by the extractive sector, but mainly by the expansion of the trade and services sector.

The city authorities contribute to the alignment of the allocation of labor resources

Using the shift-share analysis by evaluating the local effect, it was possible to identify the significant contribution of the city authorities in enhancing the attractiveness of the eastern and northern regions for labor resources under the conditions of restructuring and renewing of the Russian economy. In general, out of 98 cities surveyed, only 29 , or $29.6 \%$, have a positive local factor value, which does not completely cover the balance of changes in the number of employees in organizations in all cities, which indicates that not everywhere local authorities pay sufficient attention to the creation of favorable conditions to attract labor resources to their territories.

Table 9 presents a part of the calculation of structural shifts in employment in Russian cities for the period 2009-2015, differentiated by the magnitude of the local factor LS.

Among the leading cities and laggards, there are mainly "capitals" of regions, which is explained by the scale of cities. The calculation of structural shifts by absolute values brings to the forefront cities with a larger population. Attention is drawn to the fact that in the first group there is a peripheral city of Norilsk in the Siberian Federal District, the increase in the number of employees in organizations by $4.45 \%$ is due to the influence of the local LS factor.

It is also interesting that Tyumen and Blagoveshchensk, which are much smaller in population, attract more than 2 times more workers than Kazan in the Volga Federal District. This may mean that "capitals" and "periphery" have equal chances in using their own competitive advantages. It is only the effective management of the municipality.

Table 8. Changes in the number of employees in organizations in cities of the Siberian Federal District, 2009-2015, \%

Source: calculated by the authors according to Rosstat.

\begin{tabular}{|c|c|c|c|c|}
\hline \multirow{3}{*}{ Type of activity } & \multirow{3}{*}{$\begin{array}{c}\text { The share } \\
\text { of total } \\
\text { employment } \\
\text { in } 2015\end{array}$} & \multicolumn{3}{|c|}{$\begin{array}{l}\text { Changes in the number of employees } \\
\text { in organizations }\end{array}$} \\
\hline & & \multirow{2}{*}{ Total } & \multicolumn{2}{|c|}{ Including } \\
\hline & & & Capital cities & Peripheral cities \\
\hline Education & 14.40 & -6.86 & -6.68 & -7.82 \\
\hline Hotels and restaurants & 0.84 & -8.85 & -7.60 & -13.47 \\
\hline Mining & 1.18 & 10.79 & 91.52 & -3.12 \\
\hline Other activities & 14.82 & -2.58 & -1.11 & -11.83 \\
\hline Health and social services & 12.81 & -0.63 & 0.46 & -5.89 \\
\hline Manufacturing & 17.02 & -13.02 & -13.37 & -11.86 \\
\hline Real estate operations, renting services & 8.53 & 1.90 & 2.27 & -1.53 \\
\hline $\begin{array}{l}\text { Wholesale and retail trade; repair of motor vehicles, } \\
\text { motorcycles, household products and personal items }\end{array}$ & 8.52 & 37.86 & 38.26 & 33.67 \\
\hline Other communal, social and personal services & 3.67 & -9.08 & -6.92 & -21.02 \\
\hline $\begin{array}{l}\text { Production and distribution of electricity, gas and } \\
\text { water }\end{array}$ & 4.54 & 1.01 & 3.31 & -5.80 \\
\hline Agriculture, hunting and forestry & 0.45 & -11.29 & -10.40 & -16.61 \\
\hline Construction & 3.56 & -13.46 & -14.95 & -5.22 \\
\hline Transport and communication & 9.65 & -4.00 & -2.17 & -13.82 \\
\hline Total & 100.00 & -2.81 & -1.69 & -8.16 \\
\hline
\end{tabular}


Table 9. The calculation of structural shifts in employment in Russian cities, 2009-2015, thousand people

Source: calculated by the authors according to Rosstat.

\begin{tabular}{|c|c|c|c|c|c|c|c|c|c|}
\hline \multirow[t]{2}{*}{ City } & \multicolumn{2}{|c|}{$\begin{array}{l}\text { The number of } \\
\text { employees in } \\
\text { organizations }\end{array}$} & \multirow[t]{2}{*}{$N S$} & \multirow[t]{2}{*}{$I S$} & \multirow[t]{2}{*}{$R S$} & \multirow[t]{2}{*}{$L S$} & \multirow[t]{2}{*}{$\Delta l$} & \multirow{2}{*}{$\begin{array}{c}\text { The } \\
\text { Federal } \\
\text { District }\end{array}$} & \multirow{2}{*}{$\begin{array}{c}\text { Capital } \\
\text { cities (C), } \\
\text { peripheral } \\
\text { cities (P) }\end{array}$} \\
\hline & 2009 & 2015 & & & & & & & \\
\hline Tyumen & 183,896 & 202,271 & 2,649 & $-0,455$ & $-1,937$ & 18,119 & 18,375 & UFD & C \\
\hline Blagoveshchensk & 61,154 & 74,306 & 0,881 & $-0,541$ & $-4,695$ & 17,507 & 13,152 & FEFD & C \\
\hline Yekaterinburg & 438,975 & 442,037 & 6,323 & $-3,746$ & $-10,088$ & 10,573 & 3,062 & UFD & C \\
\hline Kazan & 342,591 & 350,365 & 4,935 & $-5,933$ & $-1,158$ & 9,930 & 7,774 & VFD & C \\
\hline Krasnoyarsk & 287,013 & 293,006 & 4,134 & $-4,776$ & $-1,993$ & 8,628 & 5,993 & SFD & C \\
\hline Yuzhno-Sakhalinsk & 75,712 & 81,092 & 1,091 & 0,305 & $-3,411$ & 7,395 & 5,380 & FEFD & C \\
\hline Norilsk & 81,740 & 85,543 & 1,177 & $-1,323$ & $-3,243$ & 7,192 & 3,803 & SFD & P \\
\hline Irkutsk & 188,639 & 189,270 & 2,717 & $-2,107$ & $-5,732$ & 5,753 & 0,632 & SFD & C \\
\hline Perm & 311,042 & 296,247 & 4,480 & $-6,290$ & $-17,585$ & 4,600 & $-14,795$ & VFD & C \\
\hline Magadan & 34,824 & 32,911 & 0,502 & $-0,503$ & $-6,181$ & 4,269 & $-1,913$ & FEFD & C \\
\hline$\ldots$ & $\ldots$ & $\ldots$ & $\ldots$ & $\ldots$ & $\ldots$ & $\ldots$ & $\ldots$ & $\ldots$ & \\
\hline Kaliningrad & 138,105 & 126,265 & 1,989 & $-1,463$ & 5,666 & $-18,032$ & $-11,840$ & NWFD & C \\
\hline Novy Urengoy & 72,283 & 58,925 & 1,041 & 1,213 & 2,640 & $-18,253$ & $-13,358$ & UFD & $\mathrm{P}$ \\
\hline Izhevsk & 219,498 & 192,787 & 3,162 & $-4,705$ & $-6,490$ & $-18,677$ & $-26,711$ & VFD & C \\
\hline Ufa & 336,488 & 322,404 & 4,847 & $-3,831$ & 3,901 & $-19,001$ & $-14,084$ & VFD & $\mathrm{C}$ \\
\hline Arkhangelsk & 123,002 & 97,758 & 1,772 & $-2,037$ & $-4,743$ & $-20,236$ & $-25,244$ & NWFD & C \\
\hline Samara & 399,609 & 369,313 & 5,756 & $-3,222$ & $-11,435$ & $-21,396$ & $-30,296$ & VFD & C \\
\hline Togliatti & 242,425 & 188,019 & 3,492 & $-9,484$ & $-13,159$ & $-34,990$ & $-53,475$ & VFD & C \\
\hline Nizhnevartovsk & 104,846 & 75,687 & 1,510 & 0,461 & 5,201 & $-36,331$ & $-29,159$ & UFD & $\mathrm{P}$ \\
\hline Novosibirsk & 420,944 & 419,142 & 6,063 & $-3,297$ & 34,739 & $-39,308$ & $-1,802$ & UFD & C \\
\hline Orenburg & 260,688 & 186,718 & 3,755 & $-4,320$ & $-7,050$ & $-66,354$ & $-73,970$ & VFD & $\mathrm{C}$ \\
\hline
\end{tabular}

Note: *abbreviations in the table: NWFD - North-Western Federal District, VFD - Volga Federal District, UFD - Urals Federal District, FEFD - Far-Eastern Federal District, SFD - Siberian Federal District.

We should also note that among the first ten cities, by the magnitude of the local factor, six cities are on the territory which considered unfit for residence and work for a long time - the Far Eastern and Siberian Federal Districts. This means that the city authorities are able to make their own, decisive contribution to the recruitment of manpower.

The city authorities of administrative centers of the Ural, Far Eastern and Siberian Federal Districts are leading in the competitive struggle to attract labor resources.
At the same time, it can not be denied that state support measures for economic restructuring and renewing contribute to the increase in the attractiveness of cities in the territories of the Far East and Siberia. Public investment will provide infrastructure, as well as co-financing the construction of strategically important enterprises (Parlamentskaya gazeta: na Dalnem Vostoke, 2017). The task of the city authorities is to make maximum use of all possible support measures provided by the federal center.

\section{CONCLUSION AND DISCUSSIONS}

The issues of the regional allocation of labor resources in the context of the state policy of economic restructuring and renewal have been discussed in the scientific literature.

It is proved that the economic restructuring and renewing policy is a means of transition of the state to a higher stage of economic growth (Rostow, 1960), one of the consequences of this policy is changes in 
the allocation of labor resources (Tongxina et al., 2011). It was revealed that large cities influence decisively the economic structure of states (Edgington, 1989), while the most important factor in economic restructuring and renewal is labor mobility (Martynovich \& Lundquist, 2016).

In this article, the authors attempted to identify the consequences of economic restructuring and renewal for the regional allocation of labor resources on the basis of the comparative analysis of cities - "capitals" and "peripheries". Such an aspect was not previously considered in the works. The analysis of the number of employees in organizations in different economic sectors in 98 cities of five federal districts of Russia in 2009-2015 made it possible to draw conclusions of scientific and practical importance.

First, it has been proved that restructuring and renewal of the Russian economy, as well as in other countries, is accompanied by changes in the regional distribution of labor resources.

Secondly, positive and negative effects were revealed in the regional distribution of labor resources during the period of restructuring and renovation of the Russian economy. Earlier, the scientists noted at the trend of migration to the center and west of Russia in the $20^{\text {th }}$ and $21^{\text {st }}$ centuries (Kolomak, 2017). In this study, the authors identified the flow of labor resources to the regions of the Ural, Siberian and Far Eastern Federal Districts, which is a positive effect that facilitates equalization in the allocation of labor resources in the federal districts of Russia.

Among the negative effects, the authors singled out the continuing expansion of the mining sector, "slow dying" of peripheral cities, and reduction in the labor potential of cities and regions that were previously leaders in economic development. The findings of the study are consistent with the findings of Pan and Song (2017) who, using the example of China, showed that regions with the "old economy" will be forced to look more actively for ways to renovate their own economic structure. Otherwise, such regions risk falling into the group of outsiders and there will be a new round of imbalance in regions' development, and economic growth in the country will be achieved by new leaders-regions (Ahrend, 2008).

The study also shows that in "peripheral" cities, the replacement of the manufacturing sector by the tentiary sector takes place at a higher rate than in "capitals" of the region. At the same time, the share of the number of workers in organizations in the tentiary sector has already reached $70 \%$. Taking into account that the indicators analyzed in the article do not include emploees involved in small business, this share is actually even higher. For cities with traditional industrial specialization, which are quite numerous in Russia, this situation can lead to the formation of the "unviable economic structure" in peripheral cities and to the increase in the outflow of the able-bodied population to "capitals".

The authors believe that, while maintaining the above trends in the economic structure of Russian cities, the chances for success implementing the restructuring and renovation policy are small. Supporting the raw materials sectors of the economy in the regions of the Far Eastern and Siberian Federal Districts, the Russian government risks falling into the "bear trap" (Gaddy \& Ickes, 2013) - a situation where high natural rent makes investments more attractive to extractive industries, which increases the problem of resource dependence. Such a conclusion can be as a good warning for decision-making authorities, but does not give grounds to the total denial of the restructuring and renewal success. One of the reserves is to increase local self-government efficiency. The work shows that "capitals" and "periphery" have the same chances in using competitive advantages of local territories. This conclusion supports a general discussion on the role of regional authorities in the development of their territories (Oduro-Ofori, 2011).

Prospects for further research. Prospects for further research are related to a comparative analysis of the economic restructuring and renewal policy in Japan and China in order to adapt the positive experience for Russian public administration. 


\section{FUNDING/ACKNOWLEDGEMENT}

The work was carried out within the framework of the grant financing: regional tender "Volga lands in the history and culture of Russia" 2016 - Samara region. The project type is $16-12-63004$. Project theme: "Actual issues of integration, diversification and modernization of the regional industrial complex". Number of state registration of R \& D: AAAA-A16-116041310109-7.

\section{REFERENCES}

1. Ahrend, R. (2008). Understanding Russian Regions' Economic Performance during Periods of Decline and Growth: An Extreme-bound Analysis Approach (OECD Economics Department Working Papers, No. 644). OECD Publishing: Paris. https://doi. org/10.1787/235866010670

2. Arcelus, F. J. (1984). An extension of shift-share analysis. Growth and Change, 15(1), 3-8. https://doi. org/10.1111/J.в 1468-2257.1984. tb00719.x

3. Artige, L., \& Neuss, L. (2015). A New Shift-Share Method. Growth and Change, 45(4), 667683. https://doi.org/10.1111/ grow. 12065

4. Bell, D. (1976). The Coming of Post-Industrial Society. N.Y.: Basic Books.

5. Bennett, M. (2016). The Silk Road goes north: Russia’s role within China's Belt and Road Initiative. Area Development and Policy. Advance online publication. http:// dx.doi.org/10.1080/23792949.201 6.1239508

6. Coenen, L., Moodysson, J., \& Martin, H. (2015). Path Renewal in Old Industrial Regions: Possibilities and Limitations for Regional Innovation Policy. Regional Studies, 49(5), 850-865. https://doi.org/10.1080/00343404. 2014.979321

7. Dawkins, C. J. (2003). Regional Development Theory: Conceptual Foundations, Classic Works, and Research Developments. Journal of Planning Literature, 18(2), 131172.

8. Dunn, E. S. (1960). A Statistical and Analytical Technique for Regional Analysis. Papers in Regional
Science, 6(1), 97-112. https://doi. org/10.1111/j.1435-5597.1960. tb01705.x

9. Edgington, D. (1989). The Consequences of Economic Restructuring for Melbourne's Metropolitan Policy. Urban Policy and Research, 7(2), 51-59. https://doi.org/10.1080 /08111148908551387

10. Esteban-Marquillas, J. M. (1972). A Reinterpretation of Shift-Share Analysis. Regional and Urban Economics, 2(3), 249-261. Retrieved from http://esteban.iae-csic.org/ pdf/Shift_Share1.pdf

11. Fang, C., Wang, D., \& Yue, Q. (2009). Flying Geese within Borders: How China Sustains Its Labor-intensive Industries? Economic Research Journal, 9, 4-14 (in Chinese).

12. Gaddy, C. G., \& Ickes, B. W. (2013). Bear Treaps on Russia's Road to Modernization. New York: Routledge.

13. Gerasimenko, Т. (2012). Какие существенные изменения претерпела территориальная организация российского общества за постсоветский период? Что в ней осталось неизменным? [Kakie suschestvennye izmeneniya preterpela territorialnaya organizatsiya rossiyskogo obschestva za postsovetskiy period? Chto v ney ostalos neizmennym?] In A. Druzhinin, V. Kolosov, V. Shuvalov (Eds.), Пространство современной России: возможности и барьеры развития (размышления географов-обществоведов) [Prostranstvo sovremennoy Rossii: vozmozhnosti i barery razvitiya (razmyshleniya geografov-obschestvovedov)] (pp. 17-21). Moscow:
Vuzovskaya kniga. Retrieved from https://isep.sfedu.ru/sites/default/ files/study/МОНОГРАФИЯ.pdf

14. Gilbert, A. (1988). The new regional geography in English and French-speaking countries. Progress in Human Geography, 12(2), 208-228.

15. Graham, T. (2016). Washington's strategy is a relic of a bygone era. The national Interest, June 6. Retrieved from http://nationalinterest.org/feature/americaneeds-break-its-old-habits-russia16475 ? page $=2$

16. Guriev, S., \& Andrienko, Y. (2004). Determinants of interregional mobility in Russia - Evidence from panel data. Economics of Transition, 12(1), 1-27. https://doi.org/10.1111/j.09670750.2004.00170.x

17. Hill, F., \& Gaddy, C. (2003). The Siberian Curse. How Communist Planners Left Russia Out in the Cold. Washington, DC: Brookings Press.

18. Jin, J. (2015). The true intent behind China's AIIB strategy. Fujitsu Research Institute. Retrieved from http://www.fujitsu.com/ jp/group/fri/en/column/message/2015/2015-08-25.html

19. Khmeleva, G. A., \& Egorova, K. S. (2016). Structural shift in a city labor market: globalization and local effects. In T. Tomas Kliestik (Ed.), $16^{\text {th }}$ International Scientific Conference Globalization and Its Socio-Economic Consequences (pp. 855-863). ZU - University Zilina, Slovakia. Retrieved from http:// ke.uniza.sk/en/conference

20. Khmeleva, G. A., \& Bulavko, O. A. (2016). From the 2008 to the 2014 crisis: response of the labor 
market of Russia's largest cities. International Journal of Environmental and Science Education, 11(10), 3791-3806.

21. Kolomak, E. (2017). The postSoviet evolution of the Russian urban system. Area Development and Policy, 2(1), 24-39. https://doi. org/10.1080/23792949.2016.127 8176

22. Lewis, W. A. (1959). The Theory of Economic Growth. N.Y.

23. Makhrova, A., Nefedova, T., \& Pallot, J. (2017). The specifics and spatial structure of circular migration in Russia. Eurasian Geography and Economics. Advance online publication. Retrieved from http:// dx.doi.org/10.1080/15387216.201 6.1274663

24. Martynovich, M., \& Lundquist, K. J. (2016). Technological Change and Geographical Reallocation of Labour: On the Role of Leading Industries. Regional Studies, 50(10), 1633-1647. https://doi.org/ 10.1080/00343404.2015.1052062

25. Mikhailova, T. (2012a). Gulag, WWII and the long-run patterns of Soviet city growth (Working Paper. Econstor. Leibniz Information Centre for Economics). Retrieved from http://hdl.handle. net/10419/121963

26. Mikhailova, T. (2012b). Where Russians should live: A counterfactual alternative to Soviet location policy (Working Paper. Econstor. Leibniz Information Centre for Economics). Retrieved from http://hdl.handle. net/10419/121959

27. Nefedova, T. (2009). Поляризация пространства России: ареалы роста и «Черные дыры» [Polyarizatsiya prostranstva Rossii: arealy rosta i "Chernye dyry"]. Ekonomicheskaya nauka sovremennoy Rossii, 1, 62-77. Retrieved from http://cyberleninka.ru/article/n/polyarizatsiya- prostranstva-rossii-arealy-rosta-ichernye-dyry

28. Nurkse, R. (1955). Problems of Capital Formation in Underdeveloped Countries. Oxford.

29. Oduro-Ofori, E. (2011). The role of local government in local economic development promotion at the district level in Ghana: a study of the Ejisu-Juaben municipal assembly (274 p.). Technical university Dortmund, Dortmund (English).

30. Pan, M., \& Song, H. (2017). Transformation and upgrading of old industrial zones on collective land: Empirical study on revitalization in Nanshan. Habitat International, 1(65), 1-12. Retrieved from https://doi.org/10.1016/j.habitatint.2017.04.014

31. Perkins, D., Radelet, S., Snodgrass, D., Gillis, M., \& Roemer, M. (2001). Economics of Development $\left(5^{\text {th }}\right.$ ed). Norton: New York.

32. Rosenstein-Rodan, P. (1943). Problems of Industrialization of Eastern and Southeastern Europe. Economic Journal, June-September, 202-211.

33. Rostow, W. W. (1952). The Process of Economic Growth. N. Y.: W. W. Norton.

34. Rostow, W. W. (1960). The Stages of Economic Growth: A Non-Communist Manifesto. Cambridge (UK): Cambridge Univ. Press.

35. Rostow, W. W. (1971). Politics and the Stages of Growth. Cambridge, p. 230.

36. Schumpeter, J. A. (1961). The Theory of Economic Development: An inquiry into profits, capital, credit, interest, and the business cycle. Oxford University Press: New York.

37. Shabad, T. (1989). Siberian Development under Gorbachev. International Regional Science Review, 12(3), 281-289.
38. Shtyrov, V. (Interviewee). (2008). Мегапроекты России: тандем государства и бизнеса [Megaproekty Rossii: tandem gosudarstva i biznesa] [Interview transcript]. Retrieved from Parlamentskaya gazeta: na Dalnem Vostoke website: http://www.parldv.ru/384 (accessed on February 20, 2017).

39. Solow, R. M. (1957). Technical change and the aggregate production function. Review of Econom$i c s$ and Statistics, 39, 312-321.

40. Staley, E. (1944). World Economic Development: Effects on Advanced Industrial Countries. Montreal: International Labour Office.

41. Todaro, M., \& Smith, S. (2009). Economic Development. AddisonWesley: London.

42. Tongxina, A., Yuejinb, F., \& Huan, Z. (2011). An Analysis of the Model of China's Industrial Restructuring and Upgrading-Borrowing Ideas from the Experience of Japan. Energy Procedia, 5, 14611466. Retrieved from http://ac.elscdn.com/S1876610211011866/1s2.0-S1876610211011866-main. pdf?_tid=660628646167-11e7-84e6-00000aab0f6b\&acdnat $=1499248418$ _ e33d5b35bfe6e6a7ef0a06864cec126c

43. Wilson, P., Chern, T. S., Ping, T.S., \& Robinson, E. (2005). A Dynamic Shift Share Analysis of the Electronics Export Market 1988-2001: Can the NIEs Compete with China? Department of Economics (SCAPE Working Paper Series). Retrieved from http/nt2.fas.nus.edu.sg/es/pub/ wp-scape/0507.pdf. https://doi. org/10.12691/ajrd-1-5-1

44. Zimmerbauer, K. (2013). Unusual Regionalism in Northern Europe: The Barents Region in the Making. Regional Studies, 47(1), 89-103. https://doi.org/10.1080/00343404. 2011.644236 